\title{
Regulation of Monoclonal Immunoglobulin G Synthesis by Antiidiotypic Antibody in a Patient with Hypogammaglobulinemia
}

\author{
Faud Mudawwar, Zuhayr Awdeh, Kenneth Ault, and Raif S. Geha, \\ Departments of Pediatrics and Pathology, Harvard Medical School, Divisions of \\ Allergy and Immunology, Department of Medicine, Children's Hospital Medical \\ Center, Division of Hematology, Peter Bent Brigham Hospital, and the Center for \\ Blood Research, Boston, Massachusetts 02115
}

\begin{abstract}
A B S T RACT The regulation of in vitro antibody synthesis by antiidiotypic antibodies was studied in a child with hypogammaglobulinemia and a serum immunoglobulin (Ig) $G_{1 \kappa} M$ component. A rabbit antiserum was raised against the purified $M$ component and was rendered idiotype specific by extensive absorption with Cohn fraction II and with IgG derived from the patient's parents. Hemagglutination-inhibition studies demonstrated that $<1$ in 300,000 molecules of pooled human IgG carried $\mathrm{M}$ component-related idiotypic determinants. $12 \%$ of the patient's B cells, but none of her $\mathrm{T}$ cells, expressed idiotypic determinants on their surface. Spontaneous de novo synthesis of the $\mathrm{M}$ component by the patient's peripheral blood lymphocytes was demonstrated in vitro and was shown to proceed independently of the polyclonal activator pokeweed mitogen. Antiidiotypic rabbit IgG, but not its $\mathrm{F}\left(\mathrm{ab}^{\prime}\right)_{2}$, fragments profoundly inhibited the synthesis of $\mathrm{M}$ component by the patient's peripheral blood lymphocytes. We concluded that antiidiotypic antibodies may play a role in the regulation of antibody synthesis in man.
\end{abstract}

\section{INRODUCTION}

It is now well established that antiidiotypic antibodies play a role in the regulation of the immune response of experimental animals (1-3). Antiidiotypic heteroantisera have been raised against human myeloma proteins (4), M components (5), and antitetanus toxoid antibodies (6). The role of antiidiotypic antibodies in the regulation of the human antibody response remains unknown. It has been shown, how-

Received for publication 28 September 1979 and in revised form 14 December 1979. ever, that human B cells $(5,7)$, and in some cases human $\mathrm{T}$ cells $(8,9)$ derived from patients and from normal individuals, express idiotypic determinants and, therefore, can serve as targets for regulation by antiidiotypic antibodies.

In the present work, a rabbit antiidiotypic antiserum was raised against an $M$ component present in the serum of a child with hypogammaglobulinemia. The antiidiotypic antiserum profoundly suppressed the synthesis of the $\mathrm{M}$ component by the patient's $B$ cells in vitro. The suppressor activity of the antiserum was idiotypic specific and was dependent on the presence of an intact Fc fragment.

\section{METHODS}

Case report. A 5-yr-old Lebanese female with hypogammaglobulinemia, diagnosed at the American University Hospital in Beirut, Lebanon, in the 1st year of life, was admitted in May 1978 to the Children's Hospital Medical Center because of recurrent sinopulmonary infections despite gammaglobulin replacement therapy. Upon admission, serum immunoglobulin (Ig)G was $520 \mathrm{mg} / 100 \mathrm{ml}$, serum IgA was $10 \mathrm{mg} / 100 \mathrm{ml}$, and serum IgM was $22 \mathrm{mg} / 100 \mathrm{ml}$. Serum protein electrophoresis in agarose and isoelectric focusing on agarose plates (10) revealed the presence of a discrete $\mathbf{M}$ component which had not been identified in a serum specimen taken at $2 \mathrm{yr}$ of age when the child was last seen. The patient had no bone pains and no bone lesions on radiographic examination. The $M$ component was shown to persist when the child was seen a year later in May 1979. The studies reported herein, with the antiidiotypic antiserum to the $M$ component, were performed during this second visit in May 1979. The child died in September 1979 from postoperative complications of a lobectomy performed at the American University Hospital in Lebanon.

In vitro studies of $T$-cell function revealed no abnormalities in $\mathrm{T}$-cell number or $\mathrm{T}$-cell function as assessed by proliferation in response to mitogens and antigens and by the capacity to produce the nonspecific T-cell helper factor that induces polyclonal activation of B cells (11). Furthermore, no suppressor activity for Ig synthesis was detected in co-culture 
experiments of the patient's peripheral blood lymphocytes $(\mathrm{PBL})^{1}$ and PBL from normal donors (11).

Purification and characterization of the $M$ component. The $\mathbf{M}$ component was isolated from the serum by precipitation with $35 \%$ saturated $\left(\mathrm{NH}_{4}\right)_{2} \mathrm{SO}_{4}$ at $4^{\circ} \mathrm{C}$. The precipitate was dissolved in water, dialyzed against $0.007 \mathrm{M}$ phosphate buffer, $\mathrm{pH}$ 7.5, applied on a DEAE-cellulose column (Whatman DE, Whatman, Inc., Clifton, N. J.), and eluted with a linear gradient of 0.007-0.1 M phosphate buffer, $\mathrm{pH} 7.4$. The purity of the myeloma protein was established by gel isoelectric focusing and by immunoelectrophoresis. Ouchterlony analysis of the isolated $\mathbf{M}$ component was performed with IgG subclass-specific antisera obtained from Dr. Peter Schur (Robert Bent Brigham Hospital, Boston). The M component was screened for rheumatoid factor activity and for reactivity against $\mathrm{Gm}$ allotypes of human IgG by previously established methods (12).

Production of antidiotypic antisera to the $M$ component. The purified $M$ component was concentrated to $2.2 \mathrm{mg} / \mathrm{ml}$, dialyzed against $0.1 \mathrm{M}$ acetate buffer, $\mathrm{pH} 4.5$, and then incubated with pepsin (Sigma Chemical Co., St. Louis, Mo.) at a 50:1 protein to enzyme ratio for $36 \mathrm{~h}$ at $37^{\circ} \mathrm{C}$. At the end of the incubation, the reaction was terminated by adjusting the pH to 8.0 with $2 \mathrm{~N} \mathrm{NaOH}$. The material was then applied to a G-150 column (Pharmacia Fine Chemicals, Div. of Pharmacia Inc., Piscataway, N. J.). Ouchterlony analysis (using rabbit antisera to human Fc, Fab, and IgG) verified that the second protein peak eluting from the column consisted exclusively of $F\left(a b^{\prime}\right)_{2}$ fragments of IgG. This fraction was concentrated to $1 \mathrm{mg} / \mathrm{ml}$ and used for immunization. An albino rabbit weighing $3-4 \mathrm{~kg}$ (Pine Acre Rabbitery, Norton, Mass.) initially received $1 \mathrm{mg}$ of the immunogen emulsified in an equal volume of complete Freund's adjuvant (Difco Laboratories, Detroit, Mich.). Three booster immunizations of $0.4 \mathrm{mg}$ each in incomplete Freund's adjuvant were given at weekly intervals and the rabbit was bled $2 \mathrm{wk}$ after the last booster dose.

Absorption of rabbit antiserum. The IgG fraction was isolated from rabbit serum by DEAE-column chromatography using a $0.01 \mathrm{M}$ phosphate buffer, $\mathrm{pH} 6.8$. To render the antiserum idiotype specific, $20 \mathrm{mg}$ of rabbit IgG was absorbed sequentially against the following materials crosslinked to Sepharose 4B: $100 \mathrm{mg}$ of IgG derived from the patient's father, $100 \mathrm{mg}$ derived from the patient's mother, and $200 \mathrm{mg}$ of Cohn Fraction II (Massachusetts Biological Institute, Boston, Mass.). $\mathrm{F}\left(\mathrm{ab}^{\prime}\right)_{2}$ fragments were prepared from the rabbit IgG as described above.

Hemagglutination assays. Sheep erythrocytes were coated with the following proteins by the chromic chloride method (13): purified M component, pooled human IgG (Cohn fraction II), IgG Iא $_{1 \kappa}$ myeloma protein, kappa and lambda Bence Jones proteins. Equal volumes of a $1 \%$ suspension of protein-coated erythrocytes and of serial twofold dilutions of preimmune and postimmune rabbit IgG (preabsorbed with sheep erythrocytes) were mixed in the round-bottom wells of 96 well microtiter plates (Cooke Engineering Co., Alexandria, Va.). The antibody titer was read as the reciprocal of the last dilution where agglutination of the erythocytes has occurred. In other experiments, the ability of various proteins to agglutinate sheep erythrocytes coated with antiidiotypic rabbit IgG was assayed as previously described.

Hemagglutination-inhibition assay. Dilutions of various inhibitors ( $M$ component, patient's serum, pooled IgG, IgG $_{1 \kappa}$ myeloma protein, and kappa and lambda Bence

${ }^{1}$ Abbreviations used in this paper: D, deviation; PBL, peripheral blood lymphocytes; PWM, pokeweed mitogen.
Jones proteins) were premixed in the microtiter wells with rabbit antiidiotypic IgG used at a dilution two tubes to the left of the end point of the hemagglutination assay described above. After a l-h incubation at room temperature, sheep erythrocytes coated with the patient's $M$ component were added. All reagents were preabsorbed with sheep erythrocytes.

Radioimmunoassay of antiidiotypic antisera. $10 \mu \mathrm{g}$ of $\mathrm{F}\left(\mathrm{ab}^{\prime}\right)_{2} \mathrm{M}$ component were radiolabeled with ${ }^{125} \mathrm{I}$ by the chloramine T method (14) to a specific activity of $1,000 \mathrm{cpm} / \mathrm{ng}$. Each in a set of conical plastic Beckman microfuge tubes (Beckman Instruments, Inc., Fullerton, Calif.) received $40 \mathrm{ng}$ of ${ }^{125} \mathrm{I}-\mathrm{F}(\mathrm{ab})_{2} \quad \mathrm{M}$ component followed by $100 \mu \mathrm{l}$ of different dilutions of preimmune or immune rabbit IgG in phosphatebuffered saline. After an incubation period of $1 \mathrm{~h}$ at $37^{\circ} \mathrm{C}$, normal rabbit serum and goat anti-rabbit IgG were added at equivalence (taking into consideration the contribution of preimmune or immune rabbit IgG). The tubes were incubated again at $37^{\circ} \mathrm{C}$ for $1 \mathrm{~h}$, then at $4^{\circ} \mathrm{C}$ overnight. The precipitates that formed were washed in a Beckman microfuge for $5 \mathrm{~min}$ at $12,000 \mathrm{rpm}$ with ice-cold PBS containing $0.5 \%$ human serum albumin and $0.5 \%$ Tween 20 (washing buffer). After three washes, the precipitates were counted for radioactivity in in Tri-Carb gamma scintillation counter (Packard Instrument Co., Inc., Downers Grove, Ill.).

Inhibition of binding of radiolabeled $M$ component to antiidiotypic antiserum. The dilution of antiidiotypic antiserum necessary to precipitate $70 \%$ of the total amount of immunoprecipitable radiolabeled $\mathrm{F}\left(\mathrm{ab}^{\prime}\right)_{2} \mathrm{M}$ component was determined from the above experiment. Each in a set of Beckman microfuge tubes received, in succession, of $10 \mathrm{ng}$ of radiolabeled $\mathrm{F}\left(\mathrm{ab}^{\prime}\right)_{2} \mathrm{M}$ component, different dilutions of patient's IgG or pooled normal human IgG, and $100 \mu \mathrm{l}$ of the appropriate dilution of rabbit antiidiotypic antiserum. After an incubation period of $1 \mathrm{~h}$ at $37^{\circ} \mathrm{C}$, normal rabbit serum and goat anti-rabbit IgG were added at equivalence, and the precipitates were processed as described above.

Isolation and fractionation of PBL. PBL were isolated from heparinized blood on Ficoll-Hypaque. Cells were washed three times before use with Hanks' balanced salt solution. PBL were rosetted with sheep erythrocytes pretreated with neuraminidase (Behring Diagnostics, Woodbury, N. Y., 50 $\left.\mathrm{U} / \mathrm{ml}, 30 \mathrm{~min}, 37^{\circ} \mathrm{C}\right)$. The lymphocyte/erythrocyte mixture was then sedimented over a Ficoll-Hypaque gradient. The sheep erythrocyte nonrosetting cells were collected from the top of the gradient. The sheep erythrocyte rosette-forming cells were collected from the bottom, treated with $0.83 \%$ $\mathrm{NH}_{4} \mathrm{Cl}$ lysing buffer, washed, and used.

Immunofluorescence. Lymphocytes were cultured overnight in RPMI 1640 medium containing $5 \%$ fetal calf serum. The next day the cells were washed and suspended at $4^{\circ} \mathrm{C}$ at a concentration of $5 \times 10 \mathrm{mM}$ sodium azide. $0.1 \mathrm{ml}$ of cell suspension was incubated with an equal volume of rabbit preimmune or postimmune $\mathrm{F}\left(\mathrm{ab}^{\prime}\right)_{2}$ IgG for $30 \mathrm{~min}$ at $4^{\circ} \mathrm{C}$. The cells were then washed three times at $4^{\circ} \mathrm{C}$, suspended in $0.1 \mathrm{ml}$ of the same medium, and incubated with $0.1 \mathrm{ml}$ of fluorescein-conjugated $\mathrm{F}\left(\mathrm{ab}^{\prime}\right)_{2}$ goat anti-rabbit IgG (Cappel Laboratories, Inc., Downingtown, Pa.) for $30 \mathrm{~min}$ at $4^{\circ} \mathrm{C}$. After three washes in the same medium and two washes through a cushion of fetal calf serum, the cells were suspended in $0.1 \mathrm{ml}$ of medium and dropped on a clean glass slide precoated with poly-L-lysine (Sigma Chemical Co.). The drop was covered with a glass cover slip and the slide was read under the fluorescent light of a Zeiss Orthoplan fluorescent microscope (Carl Zeiss, Inc., New York) the number of fluorescent cells was recorded.

For the detection of the surface immunoglobulin isotype, polyvalent as well as heavy chain specific fluorescein- 
conjugated rabbit $\mathrm{F}\left(\mathrm{ab}^{\prime}\right)_{2}$ IgG (Cappel Laboratories, Inc.) were used as described previously (11).

Analysis of kappa and lambda chain distribution. Blood lymphocytes were labeled for kappa and lambda light chains using $\mathrm{F}\left(\mathrm{ab}^{\prime}\right)_{2}$ fragments of rabbit antibodies to human light chains followed by fluoresceinated goat anti-rabbit IgG antibodies. The labeled samples were analyzed on a fluorescenceactivated cell sorter exactly as described (15). The result of this analysis is two distribution curves (one for kappa and one for lambda chains) showing the number of cells labeling at increasing intensities of fluorescence. In normal persons these two cultures are nearly identical. The presence of a significant deviation of one of the curves with respect to the other indicates the presence of a population of monoclonal B lymphocytes. Previous work has shown that the test is sensitive to the presence of $10 \%$ or fewer monoclonal cells (15). A statistical test for the deviation (D) value can be applied to the distribution curves to define the degree of discordance between the two curves. The $D$ value for normal individuals $(n=10)$ ranges from 0.8 to 9.6 with a mean of $5.24 \pm 0.74$.

In vitro synthesis of IgG and $M$ component. $\mathrm{PBL}$ were cultured in RPMI 1640 medium containing $10 \% \mathrm{AB}+$ serum at $2 \times 10^{6}$ cells $/ \mathrm{ml}$ in $2-\mathrm{ml}$ aliquots in sterile $16 \times 125 \mathrm{~mm}$ Falcon culture tubes (Falcon Labware, Div. of Becton's Dickinson \& Co., Oxnard, Calif.). Cultures were incubated in the presence or absence of pokeweed mitogen (PWM) at $37^{\circ} \mathrm{C}$ in a humidified atmosphere of $5 \% \mathrm{CO}_{2}$ in air. One set of cultures received antiidiotypic rabbit $\mathrm{IgG}(1 \mathrm{mg} / \mathrm{ml})$. All cultures were made in duplicate. After $5 \mathrm{~d}$ of incubation, the cultures were washed five times with Hanks' balanced salt solution, then resuspended in half their original volume in special medium 199 (Microbiological Associates, Walkersville, Md., No. 09-415) deficient in L-valine, L-leucine, and L-isoleucine and supplemented with $10 \mu \mathrm{Ci} / \mathrm{ml}$ of ${ }^{3} \mathrm{H}$-radiolabeled amino acids and with dialyzed fetal calf serum. $48 \mathrm{~h}$ later, the culture fluid supernates were harvested, spun at $5,000 \mathrm{rpm}$ for $20 \mathrm{~min}$, filtered through a $0.45-\mu \mathrm{m}$ filter, and frozen at $-20^{\circ} \mathrm{C}$ until tested. In another set of experiments, fresh PBL were cultured directly at $4 \times 10^{6}$ cells $/ \mathrm{ml}$ in the medium containing the radiolabeled amino acids as described above. $19 \mathrm{~h}$ later, their supernates were collected and processed as just described.

De novo-made IgG and $M$ component were assayed by a "sandwich" radioimmunoassay. 0.1-ml aliquots of supernates were incubated for $1 \mathrm{~h}$ at $37^{\circ} \mathrm{C}$ with $500 \mu \mathrm{g}$ of normal rabbit IgG or of rabbit IgG directed, respectively, against human IgG and $M$ component idiotypes for $1 \mathrm{~h}$ at $37^{\circ} \mathrm{C}$. Goat anti-rabbit IgG (absorbed against human IgG crosslinked to Sepharose) was then added at equivalence; the tubes were incubated for $1 \mathrm{~h}$ at $37^{\circ} \mathrm{C}$, then for $24 \mathrm{~h}$ at $4^{\circ} \mathrm{C}$. The precipitates that formed were washed three times in ice-cold washing buffer, dissolved in $0.5 \mathrm{ml}$ of $0.5 \%$ acetic acid, transferred to counting vials containing $10 \mathrm{ml}$ of Instagel solution, and counted with a Tri-Carb liquid scintillation counter (Packard Instrument Co., Inc.). The radioactivity in precipitates containing normal rabbit IgG and goat antirabbit IgG was always $<200 \mathrm{cpm}$ and was subtracted from the value of counts per minute present in the precipitates containing rabbit anti-human IgG and rabbit antiidiotypic IgG.

\section{RESULTS}

Characterization of the $M$ component. The $M$ component eluted as a single peak from the DEAE column titer of $0.01 \mathrm{M}$ buffer, $\mathrm{pH} 7.4$, consisted of an IgG $_{1 \kappa}$ immunoglobulin with an isoelectric point of 8.6.
It possessed no rheumatoid factor activity nor antibody activity to human $\mathrm{Gm}$ allotypic antigens or to sheep erythrocyte antigen.

Characteristics and specificity of antiidiotypic antisera. Sheep erythrocytes coated with $\mathrm{M}$ component were agglutinated by antiidiotypic rabbit IgG diluted 1:2,048, but not by preimmune rabbit IgG. Antiidiotypic serum did not agglutinate sheep erythrocytes coated with Cohn fraction II. Using radioimmunoassay, it was found that high concentrations of antiidiotypic antiserum bound $>85 \%$ of ${ }^{125}$ I-radiolabeled $\mathrm{F}\left(\mathrm{ab}^{\prime}\right)_{2}$ fragments of the $\mathrm{M}$ component (Fig. 1). The binding capacity of the antiserum was estimated from the $50 \%$ binding point, defined by the radioimmunoassay titration curve to be at least $20 \mathrm{ng} / 100$ $\mu \mathrm{g}$ of rabbit IgG, whereas $2 \mathrm{mg}$ of rabbit antiidiotypic IgG bound $<0.2 \%$ of $20 \mathrm{ng}$ of radiolabeled pooled human IgG (data not shown).

The specificity of the antiidiotype antibodies was also studied by hemaglutination and radioimmunoassay. In a direct hemagglutination assay, $<10 \mathrm{ng} / \mathrm{ml}$ of $M$ component agglutinated erythrocytes coated with rabbit antiidiotypic IgG; 100,000-fold greater concentrations of pooled human IgG (Cohn fraction II) of myeloma protein matched for heavy and light chain

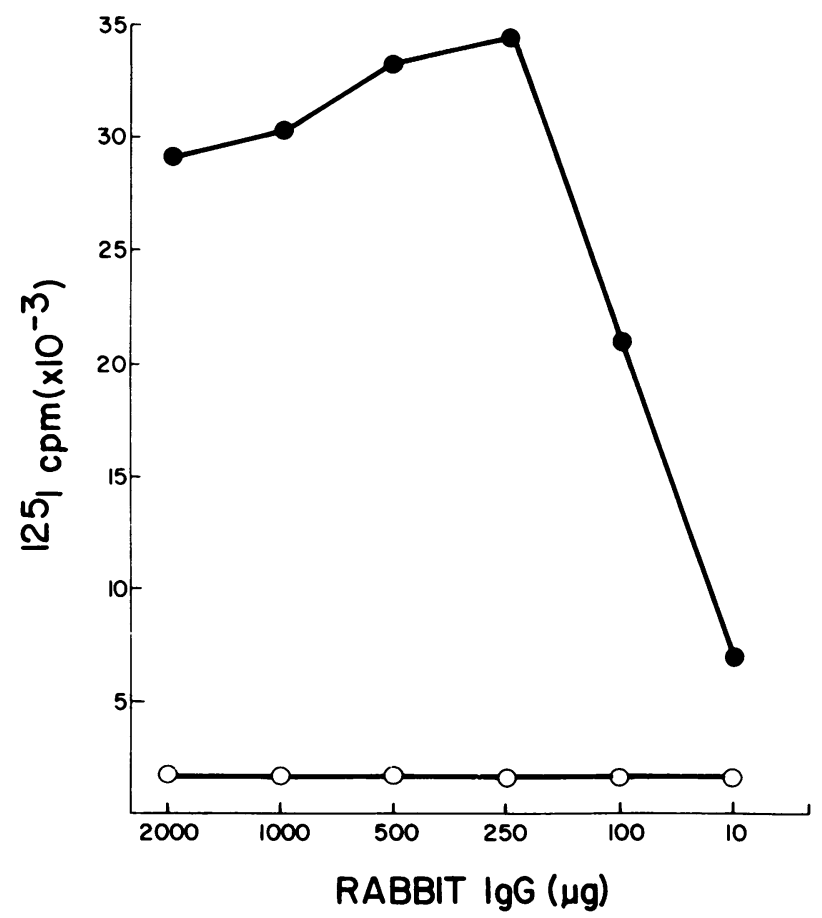

FIGURE 1 Immunoprecipitation of ${ }^{125}$ I-radiolabeled $F(a b)_{2}$ of the $M$ component by preimmune $(O)$ and postimmune $(O)$ rabbit IgG. The abscissa represents the amount of rabbit IgG (in micrograms); the ordinate represents the counts per minute of ${ }^{125} \mathrm{I}$-radiolabeled $\mathrm{F}\left(\mathrm{ab}^{\prime}\right)_{2} \mathrm{M}$ component precipitated. A total of 41,000 cpm were used in this experiment. 
class with the $\mathrm{M}$ component and of kappa and lambda Bence Jones proteins failed to achieve hemagglutination (Table I). By radioimmunoassay, the binding of ${ }^{125} \mathrm{I} F\left(\mathrm{ab}^{\prime}\right)_{2} \mathrm{M}$ component to antiidiotypic rabbit IgG was significantly inhibited by the patient's IgG but not by pooled human IgG (Cohn fraction II) (Fig. 2). $4 \mu \mathrm{g}$ of the patient's IgG almost completely inhibited the reaction, whereas $9 \mathrm{mg}$ of pooled human IgG (Cohn fraction II) failed to affect the reaction significantly. Using hemagglutinationinhibition assay, it was determined that $<1$ in 300,000 molecules of pooled human IgG (Cohn fraction II) cross-reacted idiotypically with the $\mathbf{M}$ component under study (Table II). The same assay demonstrated the presence of idiotype-positive molecules in the patient's serum taken at $2 \mathrm{yr}$ of age. These were present in $1 / 32,000$ of the amount found in the serum taken $5 \mathrm{yr}$ of age when the $\mathrm{M}$ component was first detected.

Expression of $M$ component idiotype on $P B L$ from the patient and normal donors. As determined by immunofluorescence, $6.5 \%$ of the patient's PBL were B cells; thus, her total B-cell numbers fell within the normal range. Furthermore, the patient's B cells inhibited normal isotype distribution, with the exception of a slightly elevated number of IgA-bearing cells. $0.77 \%$ of the patient's PBL, or $12 \%$ of her total $B$ cells, expressed $M$ component-related idiotypic determinants. In contrast, idiotype determinants were not expressed by the sheep erythrocyte positive T-cell enriched fraction of the patient's PBL. Sheep erythrocyte negative PBL were obtained in insufficient numbers to carry immunofluorescent staining. M component-related idiotypic determinants could not be detected on the surface of PBL from three normal blood donors (Table III).

Kappa and lambda chain distribution of patient's $P B L$. Analysis of the kappa and lambda chain distributions on the surface of the patient's PBL failed to reveal the presence of a monoclonal $B$ lymphocyte population. However, an abnormal degree of discordance between the two curves was reflected by an excessively high D value of 18.7 (normal range 0.8-9.6).

Effect of antiidiotypic antibody on the in vitro

TABLE I

Specificity Test of Antidiotypic Antibodies

\begin{tabular}{llr}
\hline $\begin{array}{c}\text { Erythrocyte-coating } \\
\text { proteins }\end{array}$ & Hemagglutinating protein & $\begin{array}{c}\text { Minimal amount for } \\
\text { hemagglutination }\end{array}$ \\
\hline \multirow{2}{*}{ Antiidiotypic IgC } & M component & $n g / m l$ \\
& Cohn fraction II & $>10$ \\
& IgG $_{1 \mathrm{~K}}$ & $>1,000,000$ \\
& Kappa Bence Jones & $>1,000,000$ \\
& Lambda Bence Jones & $>1,000,000$ \\
& & \\
\hline
\end{tabular}

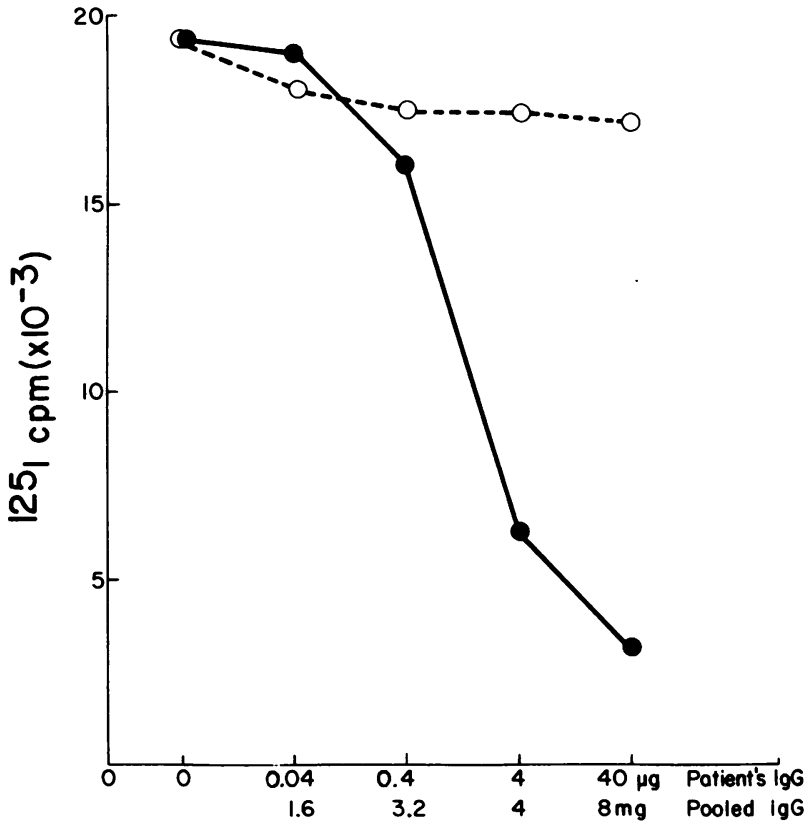

FIGURE 2 Inhibition of precipitation of ${ }^{125} \mathrm{I} \mathrm{F}\left(\mathrm{ab}^{\prime}\right)_{2} \mathrm{M}$ component by IgG derived from the patient $(O)$ and from a pool of normal donors (O). The abscissa represents the amount of patient's IgG (in micrograms) and of pooled IgG (in milligrams) used as inhibitors. The ordinate represents the counts per minute ${ }^{125}$-radiolabeled $\mathrm{F}\left(\mathrm{ab}^{\prime}\right)_{2} \mathrm{M}$ component precipitated.

synthesis of IgG and M component by PBL from the patient and normal donors. $M$ component was synthesized de novo in cultures of freshly isolated unstimulated PBL, incubated for $19 \mathrm{~h}$ in the presence of radiolabeled amino acids, as well as in cultures of $\mathrm{PBL}$ incubated for $5 \mathrm{~d}$, then washed and cultured for $48 \mathrm{~h}$ in the presence of radiolabeled amino acids (Table IV).

Almost all of the IgG secreted in vitro by the patient's PBL carried M component-related idiotypic determinants (Table IV). In contrast, idiotypic determinants were not detected on IgG secreted by normal PBL after PWM stimulation (data not shown). $M$ component

TABLE II

Inhibition of Hemagglutination of M Component-coated Erythrocytes with Antiidiotypic Antiserum

\begin{tabular}{ll}
\hline \multicolumn{1}{c}{ Inhibitor } & \multicolumn{1}{c}{$\begin{array}{c}\text { Minimum amount for } \\
\text { inhibition }\end{array}$} \\
\hline M component & $166 \mathrm{ng} / \mathrm{ml}$ \\
Cohn fraction II & $>50,000,000 \mathrm{ng} / \mathrm{ml}$ \\
Kappa Bence Jones & $>300,000 \mathrm{ng} / \mathrm{ml}$ \\
Lambda Bence Jones & $>300,000 \mathrm{ng} / \mathrm{ml}$ \\
IgG ${ }_{1 K}$ myeloma & $>300,000 \mathrm{ng} / \mathrm{ml}$ \\
Serum taken at 2 yr of age & $1: 16 \mathrm{dilution}$ \\
Serum taken at 5 yr of age & $1: 256,000 \mathrm{dilution}$ \\
Undiluted normal human serum & No inhibition \\
\hline
\end{tabular}


TABLE III

Membrane Fluorescence of $P B L$

\begin{tabular}{|c|c|c|c|c|c|c|c|c|}
\hline \multirow[b]{2}{*}{ PBL donor } & \multirow[b]{2}{*}{ Cell fraction } & \multicolumn{6}{|c|}{ Percent of cells fluorescent with antisera to: } & \multirow[b]{2}{*}{ D value } \\
\hline & & $\mathbf{I g}^{*}$ & $\mu$ & $\gamma$ & $\boldsymbol{\sigma}$ & $\delta$ & Idt & \\
\hline Patient (M.A.) & Unfractionated & 6.5 & 1.0 & 2.1 & 3.1 & 3.5 & 0.77 & 18.7 \\
\hline Patient (M.A.) & $\begin{array}{l}\text { Sheep erythrocyte } \\
\text { positive }\end{array}$ & 0.2 & 0.1 & 0.1 & 0.1 & 0.1 & 0.02 & - \\
\hline 1 & Unfractionated & 8.6 & 5.2 & 2.5 & 1.4 & 3.8 & 0.02 & Range for \\
\hline 2 & Unfractionated & 7.6 & 4.6 & 3.2 & 0.6 & 2.9 & 0.02 & normal $D$ value \\
\hline 3 & Unfractionated & 11.3 & 6.8 & 1.7 & 2.2 & 4.7 & 0.02 & is $0.8-9.6$ \\
\hline
\end{tabular}

* Ig, polyvalent immunoglobulin.

$\ddagger$ Id, M component idiotype.

synthesis by the patient's PBL was not increased by the addition of PWM to the cultures. Addition of rabbit antiidiotypic IgG to the culture medium resulted in significant inhibition of $\mathbf{M}$ component synthesis by the patient's PBL (Table IV), but did not affect IgG synthesis by normal PBL from three donors (data not shown). $\mathrm{F}\left(\mathrm{ab} \mathrm{b}^{\prime}\right)_{2}$ fragments of rabbit antiidiotypic IgG failed to inhibit $M$ component secretion by the patient's PBL.

\section{DISCUSSION}

The present study demonstrated that a rabbit heteroantiserum raised against the idiotypic determinants of an $\mathrm{M}$ component present in the serum of a child with hypogammaglobulinemia inhibited the spontaneous in vitro synthesis of the $\mathrm{M}$ component by the PBL of the patient. These findings suggest that antiidiotypic antibodies may regulate the in vitro synthesis of idiotype-bearing immunoglobulin molecules by human B cells.

$M$ components are rarely present in children. They can be seen in congenital toxoplasmosis (16) and in severe combined immunodeficiency (17). The IgG M component was first detected in the patient's serum $4 \mathrm{yr}$ after the diagnosis of hypogammaglobulinemia. However, hemagglutination-inhibition studies revealed the presence of $\mathrm{M}$ component-related cross-reactive idiotypic determinants in the serum sample taken at $2 \mathrm{hr}$ of

TABLE IV

In Vitro Synthesis of IgG and M Component by Patient's PBL

\begin{tabular}{|c|c|c|c|c|c|}
\hline \multirow[b]{2}{*}{ Experiment } & \multirow{2}{*}{$\begin{array}{l}\text { Culture } \\
\text { period }\end{array}$} & \multirow{2}{*}{$\begin{array}{l}\text { Stim- } \\
\text { ulus }\end{array}$} & \multirow[b]{2}{*}{ Inhibitor } & \multicolumn{2}{|c|}{$\begin{array}{c}{ }^{3} \mathrm{H} \text { counts per minute } \\
\text { precipitated by* }\end{array}$} \\
\hline & & & & Anti-IgG & Anti-Idt \\
\hline$n$ & & & & & \\
\hline 1 & $\begin{array}{l}0-19 \mathrm{~h} \\
120-168 \mathrm{~h}\end{array}$ & $\begin{array}{l}\text { None } \\
\text { None }\end{array}$ & $\begin{array}{l}\frac{-}{-} \\
\text { Antiidiotypic IgG } \\
\text { Antiidiotypic IgG } \mathrm{F}(\mathrm{ab})_{2}\end{array}$ & $\begin{array}{r}1,755 \pm 474 \\
2,619 \pm 448 \\
624 \pm 190 \\
(P<0.05) \\
2,167 \pm 668\end{array}$ & $\begin{array}{r}1,419 \pm 426 \\
2,360 \pm 584 \\
422 \pm 206 \\
(P<0.05) \\
1,857 \pm 343\end{array}$ \\
\hline 2 & $120-168 \mathrm{~h}$ & None & $\begin{array}{l}\text { Antiidiotypic IgG } \\
\text { Antiidiotypic IgG } \mathrm{F}(\mathrm{ab})_{2} \\
\qquad- \\
\text { Antiidiotypic IgG } \\
\text { Antiidiotypic IgG } \mathrm{F}(\mathrm{a} \bar{b})_{2}\end{array}$ & $\begin{array}{r}3,842 \pm 688 \\
520 \pm 183 \\
(P<0.05) \\
4,015 \pm 549 \\
3,753 \pm 513 \\
470 \pm 176 \\
(P<0.05) \\
\text { ND } \$\end{array}$ & $\begin{array}{c}3,662 \pm 531 \\
545 \pm 137 \\
(P<0.05) \\
4,424 \pm 806 \\
3,555 \pm 644 \\
395 \pm 119 \\
(P<0.05) \\
4,334 \pm 1,031\end{array}$ \\
\hline
\end{tabular}

* Counts per minute of specific radioactivity precipitated from 1/10 of $1 \mathrm{ml}$ of PBL culture-fluid supernates $\left(4 \times 10^{6} \mathrm{PBL} / \mathrm{ml}\right)$. Values represent mean \pm SD of two replicate cultures; the supernate of each was tested in duplicate.

I Id = anti-M component idiotype.

$\S \mathrm{ND}=$ not done. 
age ( $1 \mathrm{yr}$ after diagnosis) in an amount equivalent to $1 / 32,000$ of that present at $5 \mathrm{yr}$ of age (Table II). Serum specimen taken at the time of diagnosis was not available for study. Because the patient was receiving gammaglobulin replacement therapy, a search was made for antibody activity of the $M$ component directed against allotypic determinants of human IgG. No such activity was detected. Furthermore, the $M$ component possessed no rheumatoid factor activity and did not agglutinate sheep erythrocytes. Thus, the antibody specificity of the $M$ component remains unknown.

A heteroantiserum to the purified $M$ component was raised in the rabbit and was rendered idiotype specific by extensive absorption with pooled IgG (Cohn fraction II) and with IgG derived from the patient's father and mother. As determined by radioimmunoassay, the absorbed antiserum had a binding capacity of $20 \mathrm{ng} / 100 \mu \mathrm{g}$ of IgG for the M component. It completely failed to agglutinate erythrocytes coated with pooled human IgG, and did not precipitate radiolabeled pooled human IgG. As shown in Table I, only the immunizing $\mathbf{M}$ component agglutinated erythrocytes coated with the antiidiotypic rabbit IgG. Neither pooled IgG, nor a myeloma protein matched for the light and heavy chain isotypes of the $M$ component $\left(\operatorname{IgG}_{1 \kappa}\right)$, nor kappa or lambda Bence Jones proteins reacted with the antiidiotypic antibodies (Table I). Hemagglutination-inhibition studies (Table II) revealed $<1: 300,000$ molecules of pooled human IgG-carried $\mathrm{M}$ component-related idiotypic determinants. Furthermore, only the patient's, but not pooled, IgG (even in large excess) inhibited the precipitation of the radiolabeled $\mathrm{M}$ component by the antiidiotypic antiserum (Fig. 2).

Immunofluorescence analysis of the patient's PBL revealed a normal B-cell number and a normal isotype distribution. $\mathrm{M}$ component-related idiotypic determinants were expressed on $0.77 \%$ of the patient's PBL, but not on the PBL of three normal donors (Table III). It is unlikely that the idiotype-positive cells were monocytes because cell suspensions were incubated overnight at $37^{\circ} \mathrm{C}$ in petri dishes, and the nonadherent cells were processed for fluorescence. Furthermore, only $\mathrm{F}\left(\mathrm{ab}^{\prime}\right)_{2}$ IgG fragments were used in the fluorescence experiments. It is also unlikely that the idiotype-positive cells passively acquired the $\mathrm{M}$ component from the patient's serum because $(a)$ the cells were incubated overnight at $37^{\circ} \mathrm{C}$ in fetal calf serum - conditions that decrease binding to $F c$ receptors (5), (b) preincubation of PBL from the normal donors in the patient's serum for $1 \mathrm{~h}$ at $37^{\circ} \mathrm{C}$ followed by washing and overnight incubation in fetal calf serum did not result in the visualization of idiotype-positive cells by immunofluorescence, and $(c)$ de novo synthesis of the $\mathrm{M}$ component was demonstrated (Table IV).

Indirect evidence was obtained suggesting that the idiotype-positive cells were B cells. Indeed, the sheep erythrocyte positive T-cell-rich fraction of the patient's PBL completely failed to express $M$ component idiotypic determinants. However, direct proof that the idiotype-positive cells were B cells was not provided because purified $B$ cells were never obtained in sufficient numbers to permit immunofluorescence analysis, and staining with antiidiotypic and anti-human Ig antisera labeled with different fluorochrome was not performed. Assuming that all the idiotype-positive cells were B cells, they would have accounted for $12 \%$ of the patient's B cells. Our finding of idiotypepositive B cells is consistent with the finding of others in benign gammopathy and in multiple myeloma $(4,5)$. However, in contrast to two recent reports $(8,9), T$ cells from our patient did not express the idiotype of the serum $M$ component.

Analysis of the kappa and lambda distribution curves of the patient's PBL revealed an abnormal distribution as reflected by the deviated $D$ value, but failed to reveal the presence of a monoclonal population of $B$ lymphocytes. This may be because the idiotypepositive B cells identified by routine immunofluorescence in our patient were at different states of their differentiation; such cells would not be expected to display uniform fluorescence intensity when analzyed by the fluorescent-activated cell sorter. A similar situation, i.e., absence of monoclonal B-cell population, is seen in multiple myeloma where idiotypic determinants are present in B cells, immature B cells, and pre-B cells (18). On the other hand, because the method used in the present study identifies monoclonal B-cell populations only when such populations account for $>10 \%$ of the total B cells, we could have easily missed a monoclonal population of idiotypepositive B cells because such cells were estimated to represent only $12 \%$ of the total B cells in the patient's blood (Table III).

De novo synthesis of the $M$ component was detected in cultures of the patient's PBL but not in cultures of normal PBL. M component was synthesized de novo in cultures of freshly isolated, unstimulated PBL incubated for $19 \mathrm{~h}$ in the presence of radiolabeled amino acids, as well as in cultures of PBL incubated for $5 \mathrm{~d}$, then washed and cultured $48 \mathrm{~h}$ in the presence of radiolabeled amino acids (Table IV). The M component accounted for almost all the IgG made de novo by the patient's PBL, reflecting the situation in the serum where the $M$ component accounted for most of the circulating IgG. Synthesis of the $M$ component by the patient's PBL was not enhanced by the presence of PWM, suggesting that the $B$ cells involved in $M$ component secretion were either fully activated into the differentiation pathway toward immunoglobulin secretion or were simply not responsive to PWM stimulation. 
Addition of antiidiotypic rabbit IgG to cultures of patient's PBL resulted in profound inhibition of $M$ component synthesis (Table IV). Competition for $M$ component binding between rabbit antiidiotypic IgG added in the first $5 \mathrm{~d}$ of culture and remaining after the wash and rabbit antiidiotypic IgG used in the precipitation cannot account for the observed inhibition of $\mathrm{M}$ component synthesis because such a competition would have occurred to the same extent in cultures pretreated with $\mathrm{F}\left(\mathrm{ab}^{\prime}\right)_{2}$ fragments of the rabbit IgG that did not cause significant inhibition of $M$ component synthesis. Furthermore, even if all idiotypic determinants on the de novo-made $\mathrm{M}$ component were saturated by antiidiotypic IgG carried over after the 5-d washes; this would not account for the inhibition observed in total IgG synthesis, as the Fc determinants on the $M$ component would remain available for binding by rabbit anti-human IgG. Finally, total saturation of all idiotypic determinants by carriedover antiidiotypic IgG, if it occurred, would still allow coprecipitation of these complexes with goat anti-rabbit IgG, which was used at equivalence with $500 \mu \mathrm{g}$ of rabbit antiidiotypic IgG.

The observed inhibition of $\mathrm{M}$ component synthesis by antiidiotypic rabbit IgG cannot be the result of competition to goat anti-rabbit IgG between antiidiotypic IgG carried over from the initial 5-d culture period and the antiidiotypic IgG used in the immunoprecipitation because after the initial $5 \mathrm{~d}$ of incubation, the cells were washed five times and any amount of antiidiotypic IgG remaining and binding to de novomade ${ }^{3} \mathrm{H}$-labeled $\mathrm{M}$ component would have coprecipitated with the rabbit antiidiotypic IgG and the goat antirabbit IgG, which were used at equivalence to form the immunoprecipitate. Furthermore, is such competition did in fact occur, it would also have been seen to some extent in cultures pretreated with $\mathrm{F}\left(\mathrm{ab}^{\prime}\right)_{2}$ fragment of rabbit antiidiotypic IgG because the goat antirabbit IgG used was raised against intact rabbit IgG and was not $\mathrm{Fc}$ specific.

This inhibition was idiotype specific because addition of antiidiotypic rabbit IgG to cultures of normal PBL did not inhibit PWM-induced synthesis of IgG by these cells. The inhibitory effect of the rabbit antiidiotypic IgG was dependent on the presence of an intact $F_{c}$ fragment because $F\left(a b^{\prime}\right)_{2}$ fragments completely failed to inhibit the synthesis and secretion of the $M$ component (Table IV). A similar requirement for the $\mathrm{Fc}$ portion of antiidiotypic antibody in the inhibition of the immune response has been described in the murine system (19). The fact that only intact antiidiotypic IgG inhibited M component synthesis suggests that the inhibitory signal is mediated through the Fc portion of the antiidiotypic antibody. Such a signal could be directly delivered to the idiotype-positive $\mathrm{B}$ cell via its $\mathrm{F}_{\mathrm{c}}$ receptor or, alternatively, could be delivered via an idiotype-positive suppressor $\mathrm{T}$ cell bearing an $\mathrm{Fc}$ receptor. Such idiotype-positive $\mathrm{T}$ cells may have been present in two low a number to be detected by our immunofluorescent technique. Finally, it is also possible that presentation of the antiidiotypic antibody by macrophages via binding to their $\mathrm{Fc}$ receptor may be necessary to deliver an inhibitory signal to the B cell. Because of constraints on the amount of blood available for study and on the time available to carry out the study, the present experiments that were carried on unfractionated PBL do not allow for differentiation between these possibilities.

The inhibitory effect of rabbit antiidiotypic IgG on $M$ component secretion is not unexpected in view of the large body of evidence in experimental animals that indicates that antiidiotypic animals can regulate the immune response (21-22). Both $B$ and $T$ cells can serve as targets for the regulatory action of antiidiotypic antibodies (22-24). Indeed, idiotype suppression can result from direct interaction of antiidiotypic antibodies with the receptor of the antibody-forming B cell (22) as well as from the induction of idiotype-specific suppressor T cells by antiidiotypic antibody (23). It is not possible to determine from our experiments whether the suppression of $\mathrm{M}$ component synthesis by antiidiotypic antibody resulted from direct interaction between the antiidiotypic antibody and the idiotypebearing B cells, or whether it occurred via interaction of antiidiotypic antibody with the $T$ cells.

It has been clearly shown in experimental animals that plasmacytomas, like normal B cells, respond to regulatory signals delivered by antigen, antiidiotypic antibody, and idiotype-specific suppressor $\mathrm{T}$ cells (24, 25). It has also been shown in inbred as well as outbred animals that autoantiidiotypic antibodies arise during the course of the normal immune response and regulate idiotype expression (26-28). Thus, it is not unlikely that antiidiotypic antibody can inhibit antibody synthesis by normal B cells, and experiments in our laboratory indicate that antiidiotypic antisera to human antitetanus toxoid antibodies precisely do so (7). One may speculate that severe hypogammaglobulinemia resulted in the inability of the patient to make antiidiotypic antibody, allowing the expansion of a B-cell clone that had been activated into immunoglobulin synthesis and secretion. The reason why the $M$ component-producing B-cell clone became activated and why it escaped the defect that affected the majority of the patient's B cell is not known.

\section{ACKNOWLEDGMENTS}

The authors wish to thank Ms. Bettina Ault for technical assistance, Ms. Petra Weller for secretarial assistance, and Dr. Fred Rosen for reviewing the manuscript.

This work was supported by U. S. Public Health Service 
grants AI-05877 and CA-14723, the Hood Foundation, and by a Basil O'Connor Starter Grant, National Foundation, March of Dimes.

\section{REFERENCES}

1. Kunkel, H. G., M. Mannik, and W. R. William. 1963. Individual antigenic determinants of isolated antibodies. Science. (Wash. D. C.). 140: 1218-1219.

2. Eichmann, K. 1972. Idiotypic identity of antibodies to streptococcal carbohydrate in inbred mice. Eur. J. Immunol. 2: 301-307.

3. Cosenza, H. 1977. Detection of antiidiotypic reactive cells in the response to phosphorylcholine. Eur. J. Immunol. 6: 114-116.

4. Mellstedt, H., D. Petersson, and G. Holm. 1976. Monoclonal B lymphocytes in peripheral blood of patients with plasma cell myeloma: relation to activity of the disease. Scand. J. Haematol. 16: 112-120.

5. Holm, G., H. Mellstedt, D. Pettersson, and P. Biberfeld. 1977. Idiotypic immunoglobulin structures on blood lymphocytes in human plasma cell myeloma. Transplant Rev. 34: 139-164.

6. Geha, R. S., and R. Weinberg. 1978. Antiidiotypic antisera in man. Production and characterization of antiidiotypic antisera to human antitetanus toxoid antibodies. J. Immunol. 121: 1518-1523.

7. Geha, R. S. 1979. Idiotypic determinants on human B cells. Clin. Res. 27: 417A. (Abstr.)

8. Preud'homme, J-L., M. Klein, S. Laboume and M. Seligmann. 1977. Idiotype-bearing and antigen-binding receptors produced by blood $\mathrm{T}$ lymphocytes in a case of human myeloma. Eur. J. Immunol. 7: 840-846.

9. Lea, T., $\emptyset$. T. Førre, T. E. Michaelsen, and J. B. Natvig. 1979. Shared idiotypes on human peripheral blood B and T lymphocytes. J. Immunol. 122: 2413-2417.

10. Awdeh, A. Z., A. R. Williamson, and B. A. Askonas. 1968. Isoelectric focusing in polyacrylamide gel and its application to immunoglobulins. Nature (Lond.). 219: 66-67.

11. Geha, R. S., N. Hyslop, S. Alami, F. Farah, E. Schneeberger and F. S. Rosen. 1979. Hyper immunoglobulin M immunodeficiency (dysgammaglobulinemia): presence of immunoglobulin $\mathrm{M}$-secreting plasmacytoid cells in peripheral blood and failure of immunoglobulin $\mathrm{M}$ immunoglobulin $G$ switch in B-cell differentiation. J. Clin. Invest. 64: 385-391.

12. Ropartz, C., and L. Rivat. 1967. Determination des groupes $\mathrm{Gm}$, Iv. Isf. Detection des antiglobulines. Specifite des anti-Rh. Immunology Techniques. (Unit of Immunology, World Health Organization). 32.

13. Goding, R. W. 1976. The chronic chloride method of coupling antigens to erythrocytes: definition of some important parameters. J. Immunol. Methods. 10: 61-66.

14. Hunter, R. 1979. Standardization of the chloramine-T method of protein iodination. Proc. Soc. Exp. Biol. Med. 133: 989-992.

15. Ault, K. A. 1979. Detection of small numbers of mono- clonal B lymphocytes in the blood of patients with lymphoma. N. Engl. J. Med. 300: 1401-1405.

16. Griscelli, C., G. Desmonts, G. Baudine, and K. Fromwell. 1973. Congenital toxoplasmosis, fetal synthesis of oligoclonal immunoglobulin $G$ in intrauterine infections. J. Pediatr. 83: 20-26.

17. Geha, R. S., E. Schneeberger, J. Gatien, F. S. Rosen and E. Merler. 1974. Synthesis of an M component by circulating B lymphocytes in severe combined immunodeficiency. N. Engl. J. Med. 290: 726-728.

18. Kubagawa, H., L. B. Vogler, J. D. Capra, M. E. Conra, A. R. Lawton and M. D. Cooper. Studies on the clonal origin of multiple myeloma: use of individually specific (idiotype) antibodies to trace the oncogenic event to its earliest point of expression in B-cell differentiation. J. Exp. Med. In press.

19. Kohler, H., B. D. Richardson, D. A. Rowley, and S. Smyk. 1977. Immune response to phosphorylcholine. III. Requirement of the $\mathrm{Fc}$ portion and equal effectiveness of IgG subclasses in anti-receptor antibody induced suppression. J. Immunol. 110: 1979-1986.

20. Cosenza, H., M. G. Julius and A. A. Augustin. 1977. Idiotypes as variable region markers: analogies between receptors on phosphorylcholine-specific $\mathrm{T}$ and $\mathrm{B}$ lymphocytes. Immunol. Rev. 34: 3-33.

21. Eichmann, K., and K. Rajewsky. 1975. Induction of T and B cell immunity by antiidiotypic antibody. Eur. J. Immunol. 5: 661-666.

22. Bona, C., R. Lieberman, S. House, I. Green and W. E. Paul. 1979. Immune response to Levan. II. T independence of suppression of cross-reactive idiotypes by antiidiotypic antibodies. J. Immunol. 122: 1614-1619.

23. Owen, F. L., S. T. Ju and A. Nisonoff. 1977. Presence on idiotype specific suppressor $\mathrm{T}$ cells of receptors that interact with molecules bearing the idiotype. J. Exp. Med. 145: 1559-1566.

24. Abbas, A. K. 1979. Inhibition of antibody production in plasmacytoma cells $\mathrm{J}$. Immunol. 122: 1791-1797.

25. Rohrer, J., B. Odermatt and R. G. Lynch. 1979. Immunoregulation of murine myeloma: isologous immunization with M 315 induced idiotype specific $\mathrm{T}$ cells that suppress IgG secretion by MOPC-315 cells in vivo. J. Immunol. 122: 2011-2019.

26. Brown, J., L. Clifford and S. Rodkey. 1979. Auto-regulation of an antibody response via network-induced autoanti-idiotypes. J. Exp. Med. 150: 67-85.

27. Schrader, A., A. Edmond, G. Goidle, J. Thorbecke and G. W. Siskind. 1979. Production of auto-anti-idiotypic antibody during the normal immune response to TNPFicoll I. Occurrence in $A K R / J$ and $B A L B / c$ mice of Hapten-Augmentable, anti-TNP plaque-forming cells and their accelerated appearance in recipients of immune spleen cells. J. Exp. Med. 150: 138-153.

28. Wikler, M., J. N. Franssen, C. Cillignon, O. Leo, B. Mariame, P. Van de Walle, D. De Groote, and J. Urbain. 1979. Idiotype regulation of the immune system: common idiotypic specificities between idiotypes and antibodies raised against antiidiotypic antibodies in rabbits. J. Exp. Med. 150: 184-195. 